\title{
A Partisan National Song: The Politics of "Hail Columbia" Reconsidered
}

\author{
MYRON GRAY
}

It has been a century since Oscar Sonneck established the prevailing wisdom on America's first national song. His account of the composition, first performances, and initial publication of "Hail Columbia" remains unassailable, even though he worked without the benefit of sources, including the first edition of the song, that have since come to light. But despite Sonneck's reliability in matters of historical fact, his interpretation of "Hail Columbia" as "a non-partisan song" needs revision. ${ }^{1}$ Later writers have tended to agree, if only tacitly, with William Treat Upton, who when updating Sonneck's work thirty years on saw no reason to amend this point. Arguing that it "contains no party allusions whatsoever," Upton maintained that "Hail Columbia" originated "as a patriotic and not as a political song." This is a dubious distinction, although on the first point Upton cannot be questioned. "Hail Columbia" is rightly regarded as the preeminent musical example of the rise of patriotic feeling in pre-Jeffersonian America and as a precursor to "The Star-Spangled Banner." But in the deeply divided political climate of the late-1790s United States, no song could have hoped to inspire the kind of solidarity that has since become associated with the American national anthem. Although historians generally recognize that "Hail Columbia" trumpeted the values of John Adams's Federalist administration, something of the partisan atmosphere in which the song first circulated is obscured if "Hail Columbia" is invoked merely as a symbol of emergent nationalism. The central contention of this essay is that the patriotism associated with "Hail Columbia" was in fact political - that it was partisan by virtue of its failure to represent a true consensus on national issues.

When this anthem first resounded in theaters on the northeastern seaboard of the United States in April 1798, the nation's leaders had for years been locked in a bitter dispute concerning American relations with Europe's two leading powers, England and France. Federalists favored ties with the British at the expense of the French, Republicans the opposite, and a sour turn in Franco-American relations had lately given Federalists an edge. France's reaction to the Anglo-friendly shipping policies established by the Jay Treaty had triggered an undeclared state of naval hostilities known as the Quasi-War. Efforts to resolve this conflict ground to a halt when, in a Parisian diplomatic scandal known as the XYZ Affair, French

\footnotetext{
${ }^{1}$ Oscar Sonneck, "The First Edition of 'Hail Columbia'," Pennsylvania Magazine of History and Biography 40, no. 4 (1916): 434. Sonneck's essay refutes theories propounded in Charles Hart, "Hail Columbia' and Its First Publication: A Critical Inquiry," Pennsylvania Magazine of History and Biography 34, no. 2 (1910): 162-65. Hart had tried to discredit findings in Sonneck's initial study, "Critical Notes on the Origin of 'Hail Columbia'," Sammelbände der Internationalen Musikgesellschaft 3, no. 1 (1901): 139-66.

${ }^{2}$ Oscar Sonneck, Bibliography of Early Secular American Music, $18^{\text {th }}$ Century, revised and enlarged by William Treat Upton (New York: Da Capo, 1964 [1945]), 171 (emphasis in original). "Hail Columbia" is mentioned in more recent work including William Gibbons, “Yankee Doodle' and Nationalism, 1780-1920,” American Music 26, no. 2 (2008): 246-74; Glenda Goodman, "Musical Sleuthing in Early America: 'Derry Down' and the XYZ Affair," Common-place 13, no. 2 (2013), accessed March 12, 2016, http://www.common-place-archives.org/vol-13/no-02/goodman/; and Richard Spicer, "Popular Song for Public Celebration in Federal Portsmouth, New Hampshire," Popular Music and Society 25, no. 1 (2001): 1-99, https://doi.org/10.1080/03007760108591789. Goodman and Spicer attend carefully to political context, but neither writer openly contests Sonneck and Upton's assessment of "Hail Columbia" as a non-partisan song.
} 
officials tried to extort bribes from American negotiators. American loyalty to France weakened as a result of these events, and Federalists capitalized by promoting their political vision with redoubled intensity.

"Hail Columbia" cannot be linked to a formal government initiative, but it did belong to a loosely coordinated cultural offensive in which Federalists leveraged the French crisis to rouse support for Adams. The song's popularity attests to the success of these efforts in the spring of 1798. "Hail Columbia" cheered thousands, offering reassurance at a time when all-out war with a European power seemed imminent. Building on this momentum, songs on the model of "Hail Columbia" were written, performed, and published in its wake, and the full significance of the anthem is lost unless these are also taken into account. Comparison of "Hail Columbia" with offshoots like "Adams and Liberty" and "Columbia and Liberty" reveals a consistent narrative strategy by which Federalists represented the conflict with France. But the partisan implications of "Hail Columbia" are not limited to its text. They are also evident in its music and in paratextual practices of representation found in music-sheet editions of the song. I take this up after first discussing the origin and reception of "Hail Columbia" in its political context. In all I understand the song not as a spontaneous expression of an embryonic national spirit, but rather as part of an informal cultural program whereby Federalists represented their interests as the interests of the nation.

\section{A Parody Song for the French Crisis}

"Hail Columbia" is a vocal adaptation of "The President's March," an instrumental number that a former Hessian bandsman, Philip Phile, composed in 1789 for the inauguration of George Washington. As such, it belongs to the tradition of the parody song, a popular genre of eighteenth-century political discourse that originated across the Atlantic. Just as Jacobite writers turned the British imperialist anthem "Rule Britannia" into a tribute to Charles Edward Stuart after his failed attempt on the English throne in the 1740s, for instance, and just as American patriots converted "God Save the King" into "God Save America" in the years following the Revolutionary War, so too did Federalists recast familiar melodies to suit their purposes in the late $1790 \mathrm{~s}^{3}$ Music made good propaganda, amplifying the sentiment and broadening the appeal of political ideology. And if the music was already popular, then it did this work all the more quickly and cheaply. Parody songs circumvented the laborious process of printing musical notation and the need for consumers to read it. They were a more convenient and accessible alternative to even the simplest music sheets. Because of this, and because secular music was rarely printed in the United States before 1793, the majority of early American parody songs appeared in typographic media like broadsides, newspapers, pamphlets, and songsters. ${ }^{4}$ Even "Hail Columbia," which appeared in several

\footnotetext{
${ }^{3}$ With music by Thomas Arne and words by James Thomson, "Rule Britannia" received its premiere in 1740 at Maidenhead as part of the masque Alfred. In its first extant publication with musical notation, it appears as a supplement to Arne's Music in The fudgment of Paris (London: Waylett, [1741]), 62-64. The parody appears in Alexander Grosart, ed., English Facobite Ballads, Songs and Satires, etc. from the Mss. at Towneley Hall, Lancashire (n.p., 1877), 61. For further examples, see Murray Pittock, Poetry and Facobite Politics in Eighteenth-Century Britain and Ireland (New York: Cambridge University Press, 1994), https://doi.org/10.1017/CBO9780511519093. "God Save the King" and "God Save America" appear, respectively, in The Gentleman's Magazine and Historical Chronicle, vol. 15 (London: Cave, 1745), 552; and The Philadelphia Songster, part 1 (Philadelphia: McCulloch, 1789), 3.

${ }^{4}$ The anticipated 1793 opening of Philadelphia's Chestnut Street Theatre, which a Yellow Fever outbreak delayed until 1794, spurred the development of an American trade in printed music. Newly arrived immigrants Benjamin Carr and George Willig built successful Philadelphia publishing firms by engraving, punching, and printing from pewter plates, a method familiar in London but new to the United States. Other shops were established by Benjamin's father Joseph Carr in Baltimore, George Gilfert in New York, and Peter Albrecht von Hagen in Boston. The Carrs also ran a New York branch, which James Hewitt bought in 1797. Richard Wolfe, Early American Music Engraving and Printing (Urbana: University of
} 
music-sheet editions, was more often found in words-only formats. ${ }^{5}$

Unlike many parody songs, however, "Hail Columbia" did not subvert the politics of its source tune. "The President's March" had long been popular with Federalists. When Philadelphia's Chestnut Street Theatre opened in 1794, for instance, journalists disagreed over which melody, Phile's or the Republican favorite "Ça Ira," represented the interests of the audience. The Republican General Advertiser noted approvingly that the orchestra responded to the demand for "Ça Ira" on opening night, voluntarily repeating the tune. But when "The President's March" replaced the French song the following week in recognition of Washington's attendance at the theater, the paper objected:

If the President was expected at the Theatre on Wednesday evening last, and if the President's march was announced as the first piece to be performed by the orchestra under that expectation-the Managers certainly have mistaken the spirit of the citizens of Philadelphia. They are no friends to a mimickry [sic] of British customs and are sufficiently enlightened not to bear with patience even an indirect comparison between a king, the creature of chance, and a President, the choice of a People. ${ }^{6}$

The band eventually played "Ça Ira" that night, but not before Phile's quasi-monarchical march had slighted Republicans. ${ }^{7}$

Phile wrote "The President's March" in the same year that Parisians stormed the Bastille, and at that point the tune would not have become embroiled in such a controversy. French aid in the War of Independence was a recent memory, and the French Revolution was at first widely touted as a transatlantic extension of the American quest for liberty. It was not until the mid-1790s that the radicalization of the French Revolution fed the emergence of anti- versus pro-French partisanship. Combined with French military aggression against England (1793-1802), the violence of the Terror (1793-94) prompted Federalists to reject French republicanism. Republicans, meanwhile, hardened in their support of the French, vigorously opposed Federalist measures like the Jay Treaty (signed 1794, effective 1796) for their protection of British trade. According to the Franco-American Treaty of Alliance (1778), the United States was obliged to defend French interests, but in point of fact it remained economically reliant on Britain. What Federalists saw as a victory for national prosperity and security, Republicans deemed a betrayal of their revolutionary heritage. What neither party could deny was that the American ratification of the Jay Treaty spelled the end of naval peace with France, which in 1797 began confiscating the cargoes of U.S. ships engaged in trade with England. ${ }^{8}$

Illinois Press, 1980), 38-48.

${ }^{5}$ The Carrs, Willig, Gilfert, and Hagen issued "Hail Columbia" music sheets in 1798. The words of the song appeared in broadsides including Adams and Liberty: The Boston Patriotic Song. Together with Hail Columbia! (n.p., n.d.), Adams and Liberty, Together with Hail Columbia, and the American Sailor (n.p., n.d.), and Hail Columbia: A Federal Ode (Boston: White, n.d.); in newspapers including the Philadelphia Gazette (April 26, 1798), Daily Advertiser (New York, April 30, 1798), Commercial Advertiser (New York, May 1, 1798), Albany Gazette (May 4, 1798), Alexandria Advertiser (May 4, 1798), Weekly Museum (New York, May 5, 1798), Chelsea Courier (Norwich, Conn., May 17, 1798), and Oriental Trumpet (Portland, Maine, May 23, 1798); in pamphlets including The Annual Visitor (Baltimore: Pechin, [1798]), Franklin's Legacy (Troy, N. Y.: Moffitt, [1798]), Poor Robin's Almanac (Philadelphia: McCulloch, [1798]), Song Adapted to the President's March (Philadelphia: Ormrod, [1798]), The Vermont Almanac and Register (Rutland: Walker, [1798]), and The Virginia Almanac (Winchester: Bowen, [1798]); and in songsters including The Echo (Brookfield, Mass.: Merriam, 1798), The Humming Bird (Boston: Spotswood and Etheridge, 1798), The Fovial Songster (New York: Harrisson, 1798), The American Songster (Baltimore: Warner and Hanna, 1799), The Columbian Songster (Wrentham, Mass.: Heaton, 1799), and The Social Companion (Portsmouth, N. H.: Larkin, 1799).

6 "From a Correspondent," General Advertiser, February 28, 1794, 3.

7 "New Theatre," General Advertiser, February 28, 1794, 3.

${ }^{8}$ On American celebration of the French Revolution, see Simon Newman, Parades and the Politics of the Street: Festive Culture in the Early American Republic (Philadelphia: University of Pennsylvania Press, 1997), chapter 4, https://doi.org/10.9783/9780812200478; and David Waldstreicher, In the Midst of Perpetual Fetes: The Making of American 
Largely as a result of the division of opinion about the Jay Treaty and the French Revolution, the 1796 election was the first time Americans chose between presidential candidates who represented competing factions. Whereas Washington's election and re-election were virtually uncontested, Thomas Jefferson's loss to Adams disheartened Republicans and exacerbated tensions with France. Knowing Adams as an English sympathizer, the French government stepped up its interference with AngloAmerican trade when he took office, declaring that all U.S. ships carrying British goods were liable to capture and that American soldiers discovered on English ships would be treated as enemy pirates. In response Adams began a naval build-up, but he also sent a delegation to Paris in hopes that the conflict could be resolved peacefully.

When Charles Cotesworth Pinckney, John Marshall, and Elbridge Gerry arrived at the French capital in October 1797, they were poorly received. Charles Maurice de Talleyrand-Périgord and his representatives-denoted by the letters $\mathrm{X}, \mathrm{Y}$, and Z in Marshall's reports on the mission-would not acknowledge the Americans unless they met a series of demands, including a retraction of anti-French remarks by Adams, the absolution of existing French debt to the United States, a new U.S. loan to France, and personal tributes worth hundreds of thousands of dollars. Underlying these ultimatums was a desire for more equitable treatment from the Americans, who appeared to have become de facto allies of Britain. ${ }^{9}$ Marshall and Pinckney lost heart and sailed for home in April, while Gerry, a Republican, remained in Paris longer. Adams had already announced the failure of the mission in March, bringing the Quasi-War into full swing. Without declaring a formal state of hostilities, Congress introduced a range of measures against France. Official policies included a full trade embargo, the suspension of all treaties, permission for the navy to attack French ships that interfered with U.S. commerce, and an expanded naval budget. ${ }^{10}$ The initially widespread American endorsement of republican France was accordingly reversed-a remarkable change given the strength of pro-French sentiment among Republicans. Ironically, however, it was the Republicans who turned the tide of favor against France by demanding the publication of Marshall's Paris dispatches. Damning of the French officials, the documents vindicated the Federalist position, compelling some Republicans to renounce their political attachments. ${ }^{11}$

As its status rose in proportion to the decline in public esteem for France, "The President's March" became more popular than ever in the spring of 1798. This fact was not lost on an enterprising actor named Gilbert Fox, whose annual benefit at the Chestnut Street Theatre was scheduled for April 25. A full house would mean a full cashbox and a comfortable off-season for the performer, and Fox predicted that a vocal parody of "The President's March" would draw a big crowd. After the theater poets tried and failed to adapt the tune, Fox turned for help to a former classmate and highly regarded local wordsmith, the

\footnotetext{
Nationalism, 1776-1820 (Chapel Hill: University of North Carolina Press, 1997), 112-16 and 126-40. On the emergence of anti- versus pro-French partisanship, see Stanley Elkins and Eric McKitrick, The Age of Federalism (New York: Oxford University Press, 1993), 354-65. For a discussion of the Jay Treaty as a turning point in American domestic politics, see Marie-Jeanne Rossignol, The Nationalist Ferment: The Origins of U.S. Foreign Policy, 1789-1812, trans. Lillian Parrott (Columbus: Ohio State University Press, 2004 [1994]), 45-50; and for detailed diplomatic histories of the Jay Treaty and Quasi-War see Alexander DeConde, Entangling Alliance: Politics and Diplomacy under George Washington (Durham: Duke University Press, 1958) and The Quasi-War: The Politics and Diplomacy of the Undeclared War with France, 1797-1801 (New York: Charles Scribner's Sons, 1966).

${ }^{9}$ DeConde, Quasi-War, 17-19 and 46-59.

${ }^{10}$ Ibid., 89-98 and 103-108. For more on Adams's management of the French crisis, see Elkins and McKitrick, Age of Federalism, chapters 12-14; and Rossignol, Nationalist Ferment, 99-106.

${ }^{11}$ In an April 1798 letter to James Madison, Thomas Jefferson wrote of "wavering" Republicans fleeing to "the war party" in order to avoid association with French partisanship. Quoted in Gordon Wood, Empire of Liberty: A History of the Early Republic, 1798-1815 (New York: Oxford University Press, 2009), 243.
} 
lawyer Joseph Hopkinson, who penned "Hail Columbia" overnight. ${ }^{12}$ Fox then took Hopkinson's work to the journalist and publisher William Cobbett, an ardent Francophobe. The April 24 issue of Cobbett's newspaper included the full program of "Mr. Fox's Night," promising the premiere of "an intire [sic] NEW SONG (written by a Citizen of Philadelphia) to the Tune of the 'PrESIDENT's MARCH'."13 An editorial followed the announcement:

It is not often that I interest myself in the success of Theatrical Representations; but, I cannot help bestowing a word or two in approbation of what is advertised for tomorrow night. Mr. Fox has, with singular propriety, admitted a SONG, written by a gentleman of Philadelphia, adapted to the PRESIDENT'S MARCH, which has long been the national, and is now the popular tune. Long, much too long, have the lovers of the drama been shocked and insulted with the sacrilegious hymns of atheism and murder; and the actor, let his theatrical merits be what they may, who, by his voluntary choice, first breaks through the disgraceful practice, and appeals to the virtues in place of the vices of his audience, deserves every mark of applause, which it is in the power of the public to bestow. ${ }^{14}$

A week later the Federalist Gazette of the United States echoed these sentiments, feting Hopkinson's song while noting with relief "the entire banishment of the execrablé [sic] French murder shouts which once disgraced our places of public amusement." ${ }^{15}$ What were these maligned anthems if not the Republican favorites, "Ça Ira" and "La Marseillaise"?

According to the Philadelphia Gazette, the premiere of "Hail Columbia" received "unanimous and enthusiastic" ovations. "The introduction of a patriotic song upon the stage," it confirmed, was "a novelty interesting and welcome to Americans." Hopkinson's "stanzas were intermitted by frequent and general peals of applause, and the whole repeated in compliance with the call of the house; after which, actuated by one impulse, the audience rose and gave three loud cheers." ${ }^{16}$ Fox must have exited the stage that night a happy man. Repeated two nights later at a benefit for one of Fox's colleagues, "Hail Columbia" prompted Cobbett to print the following review:

[W] hat gave life to everything was, the SONG (which will be seen in this day's paper) written by Mr. HOPKINSON, and sung by Mr. FOX, to the tune of the President's March. Never was any thing received with applause so hearty and so universal. The Song was sung at the end of the comedy, as mentioned in bills; it was called for again at the end of the pantomime, and again after all the performances were over, and encored every time. At every repetition it was received with additional enthusiasm, 'till, towards the last, a great part of the audience, pit, box, and gallery, actually joined in the chorus.-It was very pleasing to observe, that the last stanza received particular marks of approbation. Every one was closed with long and loud clappings and huzzas, but no sooner were the words, "Behold the CHIEF WHO NOW COMMANDS," pronounced, than the house shook to its very centre; the song and the whole [band] were drowned in the enthusiastic peals of applause, and were obliged to stop and begin again and again, in order to gain a hearing. ${ }^{17}$

\footnotetext{
${ }^{12}$ Joseph Hopkinson to the Wyoming Band at Wilkes-Barre, August 24, 1840. Joseph Hopkinson (1770-1842) was a son of the Philadelphia statesman and musician Francis Hopkinson (1737-1791).

13 “New Theatre," Porcupine's Gazette, April 24, 1798, 2. The same paper advertised Benjamin Carr's publication of "Hail Columbia" on April 27. A key instrument in the Federalist effort to stir American opposition to France, Cobbett authored anti-Republican tracts including A Bone to Gnaw for the Democrats (Philadelphia: Bradford, 1795) and History of the American Facobins (Philadelphia: Cobbett, 1796).

14 "Philadelphia," Porcupine's Gazette, April 24, 1798, 2.

15 "The Managers," Gazette of the United States, May 2, 1798, 3.

16 "Theatrical," Philadelphia Gazette, April 26, 1798, 2.

17 “The Theatre," Porcupine's Gazette, April 28, 1798, 2.
} 
News of the performances reached New York, where the song soon appeared in the Daily Advertiser. ${ }^{18}$ The May 4 program for a New York theater listed "a new Patriotic SONG, called HAIL COLUMBIA ; DEATH or LIBERTY," noting that the number had been "Received in Philadelphia with more reiterated Plaudits than were perhaps ever witnessed in a Theatre." ${ }^{19}$ Music publishers rushed to print the anthem, which Hopkinson maintained "was sung at night in the streets by large assemblies of citizens, including members of Congress." The song was shortly heard "in every part of the United States." 20

Yet although "Hail Columbia" was devised, according to its author, "to get up an American spirit which should be independent of — and above the interests, passion, and policy of — both belligerents [i.e., Republicans and Federalists]," this does not mean that the song was not political. ${ }^{21}$ To appreciate the partisan spirit in which it was received, we need only consider the account that the leading Republican newspaper ran of the song's premiere:

For some days past, the Anglo Monarchical-Tory party, have appeared at the Theatre in full triumph - and the President's March and other aristocratic tunes have been loudly vociferated for, and vehemently applauded. ... On Wednesday evening . . . the admirers of British tyranny, again assembled, in consequence of the managers having announced in the bills of the day that there would be given a Patriotic song to the tune of the President's March. All the British merchants, British agents, and many of our congress tories, attended to do honor to the occasion. When the wished-for song came,-which contained, amidst the most ridiculous bombast, the vilest adulation to the Anglo-Monarchical Party, and the two Presidents-the extacy [sic] of the party knew no bounds, they encored, they shouted, they became Mad as the Priestess of the Delphic God, and in the fury of their exultation threatened to throw over, or otherwise ill treat every person who did not join heartily in the applause. . . For what reason the managers presume to offend a great body of the citizens of Philadelphia by devoting their theatre to party purposes, we are at a loss to determine; or why the Orchestra who had so readily gratified one party, should refuse to play $\mathrm{Ca}$ Ira when repeatedly called for by the others, is equally mysterious, unless the managers wish to drive from the Theatre every friend to plain republican principles, and depend alone upon the tories for support. . . It is said, that the same song is to be again sung on Friday.-The Republican party would do well therefore to absent themselves entirely from the Theatre, unless they wish to have their noses pulled by the Tories. ${ }^{22}$

This review complicates the Federalist picture of a nation joined in support of the Adams administration in the wake of the XYZ Affair. Regardless of the extent to which public approval of the president grew, and regardless of the extent to which "Hail Columbia" can be said to have united Americans, the French crisis did not reliably breed domestic reconciliation. The Republican press describes an emboldened Federalist party, reckless in its pro-British revelry. Though it must be taken with a grain of salt, this account of Republicans forcefully marginalized at the theater anticipates Adams's aggressive legislation of Federalist policies in the coming months. Having misjudged the magnitude of anti-French sentiment, the president's unflinching course of action in the spring and summer of 1798 would ultimately be his undoing.

\footnotetext{
${ }^{18}$ Daily Advertiser, April 30, 1798, 2.

19 "New Theatre," Daily Advertiser, May 3, 1798, 3.

${ }^{20}$ Hopkinson to the Wyoming Band, August 24, 1840.

${ }^{21}$ Ibid.

22 "Theatre," Aurora General Advertiser, April 27, 1798, 2.
} 


\section{The Federalist Zenith}

As Seth Cotlar has argued, the XYZ Affair prompted the formation of a "xenophobic and chauvinistic spirit" in the United States. ${ }^{23}$ The first thing that Adams did to capitalize on his newfound popularity, and to quell fears that French insurgents would infiltrate America as they had parts of Europe, was to clamp down on immigrant freedom and make it harder to become a U.S. citizen. ${ }^{24}$ His Naturalization Act (June 18) extended the residency requirement to fourteen years, mandated that immigrants report to government officials within forty-eight hours of arrival, and excluded citizenship for people from nations with which the United States was at war. Republicans opposed both this legislation and the Alien Friends Act (June 25), which empowered the president to deport any non-citizen deemed "dangerous to the peace and safety of the United States," including during peacetime. Republicans did support the Alien Enemies Act (July 6), which provided for the restraint of immigrants from enemy nations during wartime. ${ }^{25}$

Believing that oppositional journalism also threatened domestic order, Adams next turned his sights on the Republican press. Intended to shut down newspapers like Philadelphia's Aurora General Advertiser, the Sedition Act (July 14) made it illegal to maliciously or unjustly defame the established government. It had minimal impact, however, serving rather to weaken the administration in the eyes of its opponents. ${ }^{26}$ Even less popular than the Alien and Sedition Acts were the taxes that Adams levied in order to pay for military expansion. Protest to these measures culminated in the Pennsylvania Regulation of 1799, an uprising of farmers in the southeastern part of the state, led by John Fries. ${ }^{27}$ Although this resistance was suppressed without causalities, Adams's credibility had been compromised. He would ultimately resolve the French crisis by dispatching William Vans Murray to Paris, resulting in the Treaty of Mortefontaine. But unfortunately for Adams, news of this success did not reach home until he had already lost the election of 1800 to Jefferson.

Jefferson's victory brought sweeping reform in its wake, leading some to consider it a revolution in its own right. ${ }^{28}$ At the same time, however, the Republicans who took office in 1801 looked different from the party that had taken shape a decade earlier. This change, which Cotlar has labeled "the moderation of American democratic discourse," was a result of the Federalist surge that followed the XYZ Affair. ${ }^{29}$ The nativist and authoritarian spirit of the Alien and Sedition Acts would endure, and the anti-French stimulus of the Quasi-War required political adjustments of Republicans. "The universal rights of man”-a radical

\footnotetext{
${ }^{23}$ Seth Cotlar, Tom Paine's America: The Rise and Fall of Transatlantic Radicalism in the Early Republic (Charlottesville: University of Virginia Press, 2011), 98.

${ }^{24}$ Ibid., 97-111. French agitators had exploited local sympathy to overturn established regimes in the Netherlands, Switzerland, and Italy.

25 "Transcript of the Alien and Sedition Acts (1798)," U.S. National Archives and Records Administration, accessed March 12, 2016, http://www.ourdocuments.gov/doc.php?doc=16\&page=transcript. François Furstenberg has argued that the Alien Acts were meant to interfere with French designs on the Mississippi Valley, particularly the plans of suspected spies like the Comte de Volney. Furstenberg, When the United States Spoke French: Five Refugees Who Shaped a Nation (New York: Penguin, 2014), chapter 6.

${ }^{26}$ Jeffrey Pasley, “The Tyranny of Printers”: Newspaper Politics in the Early American Republic (Charlottesville: University of Virginia Press, 2001), 118-31.

${ }^{27}$ Terry Bouton, Taming Democracy: “The People," the Founders, and the Troubled Ending of the American Revolution (New York: Oxford University Press, 2007), 244-56.

${ }^{28}$ James Horn, Jan Lewis, and Peter Onuf, eds., The Revolution of 1800: Democracy, Race, and the New Republic (Charlottesville: University of Virginia Press, 2002).

${ }^{29}$ Seth Cotlar, "The Federalists' Transatlantic Cultural Offensive of 1798 and the Moderation of American Democratic Discourse," in Beyond the Founders: New Approaches to the Political History of the Early American Republic, ed. Jeffrey Pasley, Andrew Robertson, and David Waldstreicher (Chapel Hill: University of North Carolina Press, 2004).
} 
cosmopolitan slogan that had initially united the party-yielded to a measured position whereby Republicans stood for "the American people." 30 Historians recognize that this taming of democratic rhetoric extended to the realm of music, yet scholars have yet to critically examine the narratives of "Hail Columbia" and related songs. ${ }^{31}$ I now consider the role of this music in the discursive construction of American Francophobia and the related marginalization of radical cosmopolitanism. In assessing Benjamin Carr's music-sheet edition of "Hail Columbia," I contend that this prominent Philadelphian printer and arranger used visual and musical techniques to underscore the Federalism of Hopkinson's text.

\section{The Politics of "Hail Columbia"}

On its surface, "Hail Columbia" is not an inflammatory song; it is not hard to see why its partisanship has escaped commentary. Examination of Hopkinson's verse reveals similarities with other Federalist parody songs, however, drawing out themes that are otherwise easy to miss. In the words of Burton Konkle, "Hail Columbia" "brought on an epidemic" of imitations that sought to capitalize on its popularity. ${ }^{32}$ Two are considered here. "Adams and Liberty," in which the New Englander Robert Treat Paine set new words to the British melody "To Anacreon in Heaven," came closest to repeating Fox and Hopkinson's success. Paine's chosen tune originated in the 1760s as the theme song of a London music club, the Anacreontic Society. With words by the Society's president, Ralph Tomlinson, and music ascribed to a young John Stafford Smith (1750-1836), "To Anacreon" was widely known in England and America before it found enduring fame as "The Star-Spangled Banner." In the second case, "Columbia and Liberty," a certain Davenport adapted six new stanzas to Thomas Arne and James Thomson's "Rule Britannia" (1740). Neither "Adams and Liberty" nor "Columbia and Liberty" would rival "Hail Columbia," but they did mirror Hopkinson's narrative strategy and his exploitation of familiar music. One reason that the derivative songs fell short of the original is that they failed to match the discretion with which Hopkinson communicated Federalist ideology. Their occasional lack of subtlety is a boon to the present investigation, as it points up ideas that are only implicit in "Hail Columbia."

Hopkinson opens with a gesture to the revolutionary past:

First stanza of Hopkinson, "Hail Columbia” ([Philadelphia: Carr, 1798])

Hail Columbia, happy land,

Hail ye heroes, heaven-born band,

Who fought and bled in freedom's cause,

And when the storm of war was gone,

Enjoyed the peace your valor won.

\footnotetext{
${ }^{30}$ Cotlar, Tom Paine's America, 85.

${ }^{31}$ DeConde, Quasi-War, 82; Thomas Ray, “'Not One Cent for Tribute': The Public Addresses and American Popular Reaction to the XYZ Affair, 1798-99," Fournal of the Early Republic 3, no. 4 (1983): 390, https://doi.org/10.2307/3122881.

${ }^{32}$ Burton Konkle, Foseph Hopkinson, 1770-1842: Furist, Scholar, Inspirer of the Arts; Author of "Hail Columbia" (Philadelphia: University of Pennsylvania Press, 1931), 81. Music-sheet editions of such songs include "Adams and Liberty" (Boston: Linley and Moore, [1798-99]), set to "To Anacreon in Heaven"; "Brother Soldiers All Hail” (Philadelphia: Carr, [1799]), set to "Washington's March"; "The Federal Constitution and Liberty Forever" (New York: Hewitt, [1798]), set to a medley of "Washington's March at the Battle of Trenton" and "Yankee Doodle"; "The Ladies' Patriotic Song" (New York: Gilfert, [1798]), set to "Washington's March at the Battle of Trenton"; and "New Yankee Doodle" (New York: Hewitt, [1798]), set to "Yankee Doodle." Original songs with similar texts also appeared, including Henri Capron's "Come Genius of Our Happy Land" (Philadelphia: Willig, [ca. 1798]), and Victor Pelissier's "Washington and Independence" (New York: Gilfert, [ca. 1798]).
} 
Let independence be our boast,

Ever mindful what it cost,

Ever grateful for the prize,

Let its altar reach the skies.

Firm, united let us be,

Rallying 'round our liberty;

As a band of brothers joined,

Peace and safety we shall find.

No red-blooded American could object to such sentiment, and "Adams and Liberty" and "Columbia and Liberty" begin similarly:

First stanza of Paine, “Adams and Liberty" (Boston: Hagen, [1798])

Ye sons of Columbia, who bravely have fought,

For those rights, which unstained from your sires had descended,

May you long taste the blessings your valor has bought,

And your sons reap the soil which your fathers defended.

Mid the reign of mild peace, may your nation increase,

With the glory of Rome, and the wisdom of Greece;

And ne'er may the sons of Columbia be slaves,

While the earth bears a plant or the sea rolls its waves.

First and second stanzas of Davenport, "Columbia and Liberty [1798]," in A Collection of New and Favorite Songs (Philadelphia: Carr, [ca. 1800])

When Britain with despotic sway

Would at her feet our freedom lay,

We raised the standard; "To arms!" we cried;

Our patriots fought, they bled, they died.

Independent Columbians they would be,

Resolved to perish or be free.

Great Washington did then command;

He led the bold, heroic band.

They fought and conquered; Columbia's sons were free,

Resolved on death or liberty.

Independent Columbians they would be,

Resolved to perish or be free.

Each song starts with a tribute to American colonial resistance. The opening gambit in a narrative designed to convey the rationale of U.S. Francophobia in the wake of the XYZ scandal, these backward glances prepare an analogy between the American Revolution and the French conflict. As the songs turn to the present situation, Hopkinson is circumspect, avoiding explicit mention of France, whereas Paine and Davenport are unambiguous. Davenport even acknowledges the warm American reception of the initial phase of the French Revolution:

Second stanza of Hopkinson, "Hail Columbia"

Immortal patriots, rise once more,

Defend your rights, defend your shore.

Let no rude foe with impious hand 
Invade the shrine where sacred lies

Of toil and blood the well earned prize.

While offering peace secure and just,

In heaven we place a manly trust,

That truth and justice will prevail,

And every scheme of bondage fail.

Firm, united let us be,

Rallying 'round our liberty;

As a band of brothers joined,

Peace and safety we shall find.

Fourth stanza of Paine, "Adams and Liberty"

While France her huge limbs bathes recumbent in blood,

And society's base threatens with wide dissolution,

May peace like the dove who returned from the flood,

Find an ark of abode in our mild Constitution.

But though peace is our aim,

Yet the boon we disclaim,

If bought with our sovereignty, justice, or fame.

For ne'er shall the sons of Columbia be slaves,

While the earth bears a plant or the sea rolls its waves.

Third, fourth, and fifth stanzas of Davenport, "Columbia and Liberty"

When France her struggle first began

For liberty, the right of man,

Glowing with ardor in her cause,

We scorned that kings should give her laws.

Independent, may Gallia still be free;

They sought at first for liberty.

But France you now forget your friend;

Our amity is at an end.

You rob our commerce, insult us on our coast;

Divide and conquer is your boast.

Know, proud Frenchmen, united we will be,

Resolved to perish or be free.

Shall we to France a tribute pay?

Or at her feet our freedom lay?

"Forbid it, heaven!" Columbia's freemen cry,

"We will be free or nobly die."

Know, proud Frenchmen, united we will be,

Resolved to perish or be free.

As a response to the French crisis, Davenport invokes the American revolutionary alternative of liberty or death, and his final stanza confirms this resolution to hand the French the same fate as the British:

United then with heart and hand,

Our Constitution firm shall stand.

Then raise the standard, let this the motto be:

Our fathers fought, and so will we. 
Hail, Columbians! United we will be;

Like them, we'll conquer and be free.

Similar rhetoric characterizes the seventh verse of "Adams and Liberty," where a resolution to fight until death immediately follows a reference to the Quasi-War:

Let our patriots destroy anarch's pestilent worm, Lest our liberty's growth should be checked by corrosion.

Then let clouds thicken round us-we heed not the storm;

Our realm fears no shock but the earth's own explosion.

Foes assail us in vain,

Though their fleets bridge the main,

For our altars and laws with our lives we'll maintain.

And ne'er shall the sons of Columbia be slaves,

While the earth bears a plant or the sea rolls its waves.

And in his final verse even Hopkinson, having exhorted "immortal patriots" to "rise once more" in defense of American liberty, glowingly describes the U.S. Commander in Chief as "resolved on death or liberty." Although Hopkinson camouflages the partisanship of his argument, his underlying message-that the Franco-American conflict was a continuation of the past struggle against imperial England-would have been hard to miss at a time when the Quasi-War and XYZ Affair were overwhelming subjects of public discussion.

But not only does "Hail Columbia" share with other Federalist parody songs a master narrative that aligns the American Revolution and the French crisis, it contains the kind of praise for Washington that by the late 1790s had become the exclusive purview of Federalists. In the wake of the Jay Treaty, Republican newspapers like the Aurora General Advertiser dropped all pretense of deference to Washington, launching attacks on his character. In a context where virtue was an indispensable qualification for public office, this was a decisive shift. ${ }^{33}$ The Aurora accused Washington, for instance, of showing the "basest ingratitude" to France for its assistance in the War of Independence. ${ }^{34}$ "If ever a nation was debauched by a man," it alleged, "the American nation has been debauched by Washington." ${ }^{35}$ Following the 1796 election, the paper consoled its readers that, although Adams was "a professed aristocrat," he "should be preferred by republicans to George Washington." Adams had "great integrity," the reasoning went, and "would not lend his aid to the further prostitution of the American character":

it is well known that Adams is an aristocrat only in theory, but that Washington is one in practice - that Adams has the simplicity of a republican but that Washington has the ostentation of an eastern bashaw-that Adams holds none of his fellow men in slavery, but that Washington does. ${ }^{36}$

Responding to "the abusive scribblers who slander his reputation," the Federalist Gazette of the United States defended those who would "presume to say a civil thing about the character of George Washington." ${ }^{37}$ It

\footnotetext{
${ }^{33}$ On the Aurora's denigration of Washington, see Marcus Daniel, Scandal and Civility: Fournalism and the Birth of American Democracy (New York: Oxford University Press, 2009), chapter 3. On the importance of virtue in early American political leadership, and on Washington's veneration as a model of character, see Barry Schwartz, George Washington: The Making of an American Symbol (New York: Free Press, 1987); and Andrew Trees, The Founding Fathers and the Politics of Character (Princeton: Princeton University Press, 2004), 135-46.

34 "From a Correspondent," Aurora General Advertiser, December 22, 1796, 3.

35 "From a Correspondent," Aurora General Advertiser, December 23, 1796, 3.

36 "From a Correspondent," Aurora General Advertiser, December 21, 1796, 3 (emphasis in original).

${ }^{37}$ Gazette of the United States, July 25, 1796, 2.
} 
printed toasts proclaiming him an "honest man," a "patriot and hero, who has never ceased to deserve well of his country" and whose "public administration has been prosperous and glorious." ${ }^{38}$ In the same vein, the third stanza of "Hail Columbia" ascribes "godlike power" to the former president, calling for his name to "Ring through the world with loud applause." And the fourth verse represents Washington as "The rock on which the storm will beat," "Armed in virtue firm and true," and with a "steady mind from changes free." Venerating "The chief who now commands," the song offended Republicans by valorizing the status quo-the Federalist administration established by Washington and handed down to Adams. ${ }^{39}$ No matter how dire the threat that France represented to American political autonomy, this was not an impartial position to take.

In music-sheet editions of "Hail Columbia," partisan expression found outlets beyond Hopkinson's verse. Federalist producers and consumers of the song emphasized its ideological continuity with "The President's March" by placing portraits of Washington and Adams in the caption areas of "Hail Columbia" prints. This paratextual convention, replicated in editions of related parody songs, originated when Benjamin Carr undertook the first printing of "Hail Columbia." 40 The Philadelphia publisher implemented an unusual design in the title area of the plate, leaving the middle blank. In this opening he engraved an excerpt from Hopkinson's text ("Behold the chief who now commands"), intending this to serve as the caption for a portrait. The plate itself contained no illustration, only a space that allowed for a portrait to be mounted or impressed upon the sheet at a later time. ${ }^{41}$

The plate thus afforded a number of adaptations (Figs. 1a-d). Multiple mounted portraits have been identified, along with a copy where the illustration was inked onto the sheet (1a). Upton has suggested that a more widely available variant, which features a mounted portrait of Adams, was Carr's initial product (1b), ${ }^{42}$ but it seems more likely that Figure 1a represents Carr's original design. In another surviving copy a mounted portrait was removed, leaving a wax residue (1c). Evidently this illustration was more valuable to the consumer for another purpose, perhaps for inclusion in a commonplace book. Other variants display portraits of Washington instead of Adams (1d), a change that Sonneck attributes to Washington's appointment as Senior Officer of the Army. ${ }^{43}$ At all events the attachment of such images to "Hail Columbia" marks the song as an outcome of Federalist cultural praxis.

David Waldstreicher has argued that the circulation of presidential images helped Federalists to infuse their objectives with the legacy of the Revolution. Representations of Washington—and, to a lesser extent, of Adams-fostered widespread veneration and feelings of federal union. Personal encounters between the executive and the people evinced reciprocal affection, "dissolving distance in order to recreate and ratify hierarchy," and this dynamic extended to the realm of print. Looking fondly at the president was

\footnotetext{
${ }^{38}$ Gazette of the United States, August 13, 1796, 3; and March 1, 1796, 3.

${ }^{39}$ When he wrote it, Hopkinson's phrase "the chief who now commands" referred to Adams. In anticipation of full-scale war with France, however, Adams offered Washington the position of Commander-in-Chief of the U.S. Army in July 1798. Thereafter the phrase had an additional meaning. Washington served as Senior Officer of the Army until his death in December.

${ }^{40}$ Sonneck and Upton, Early Secular American Music, 171-2. "Brother Soldiers All Hail” (Philadelphia: Carr, [1799]), “The Ladies' Patriotic Song” (New York: Gilfert, [1798]), and “New Yankee Doodle” (New York: Hewitt, [1798]) also feature presidential portraits.

${ }^{41}$ Carr thus inverted the technique associated with the passe-partout title page, where a fixed illustration is combined with a blank space in which varying text can be written or printed. The London music publisher John Walsh popularized this practice in the early eighteenth century, so Carr, a native Londoner, was probably familiar with it.

${ }^{42}$ Sonneck and Upton, Early Secular American Music, 171-2.

${ }^{43}$ Ibid., 172. Figure 1d shows one of two Washington portraits that were used. The other was excised from the title page of James Hewitt's programmatic keyboard sonata The Battle of Trenton (New York: Hewitt, 1797).
} 
Figure 1: Variants of "Hail Columbia" ([Philadelphia: Carr, 1798]), title area and opening system.

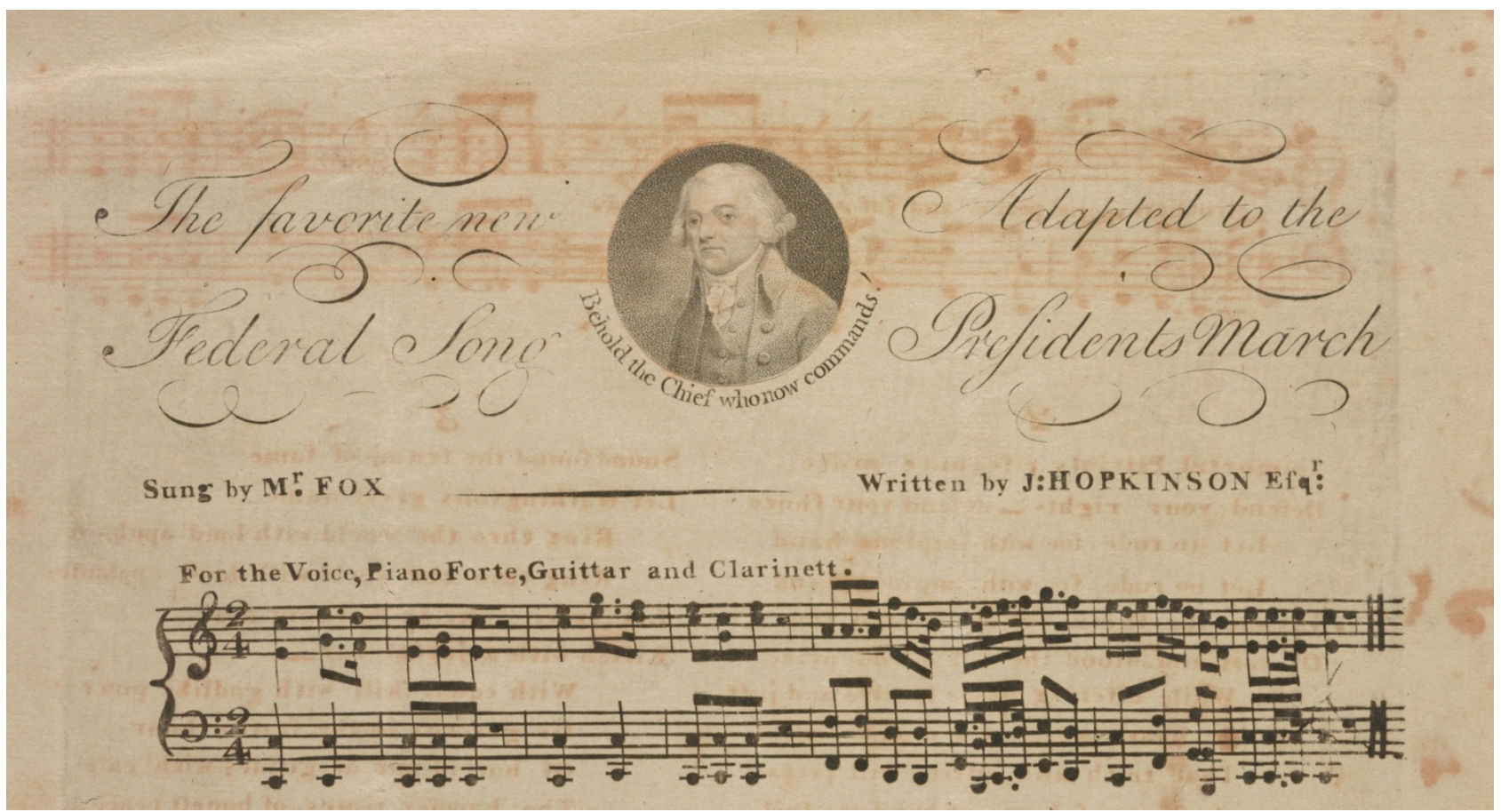

Figure 1a: Adams Portrait 1 (Music Division, Library of Congress)

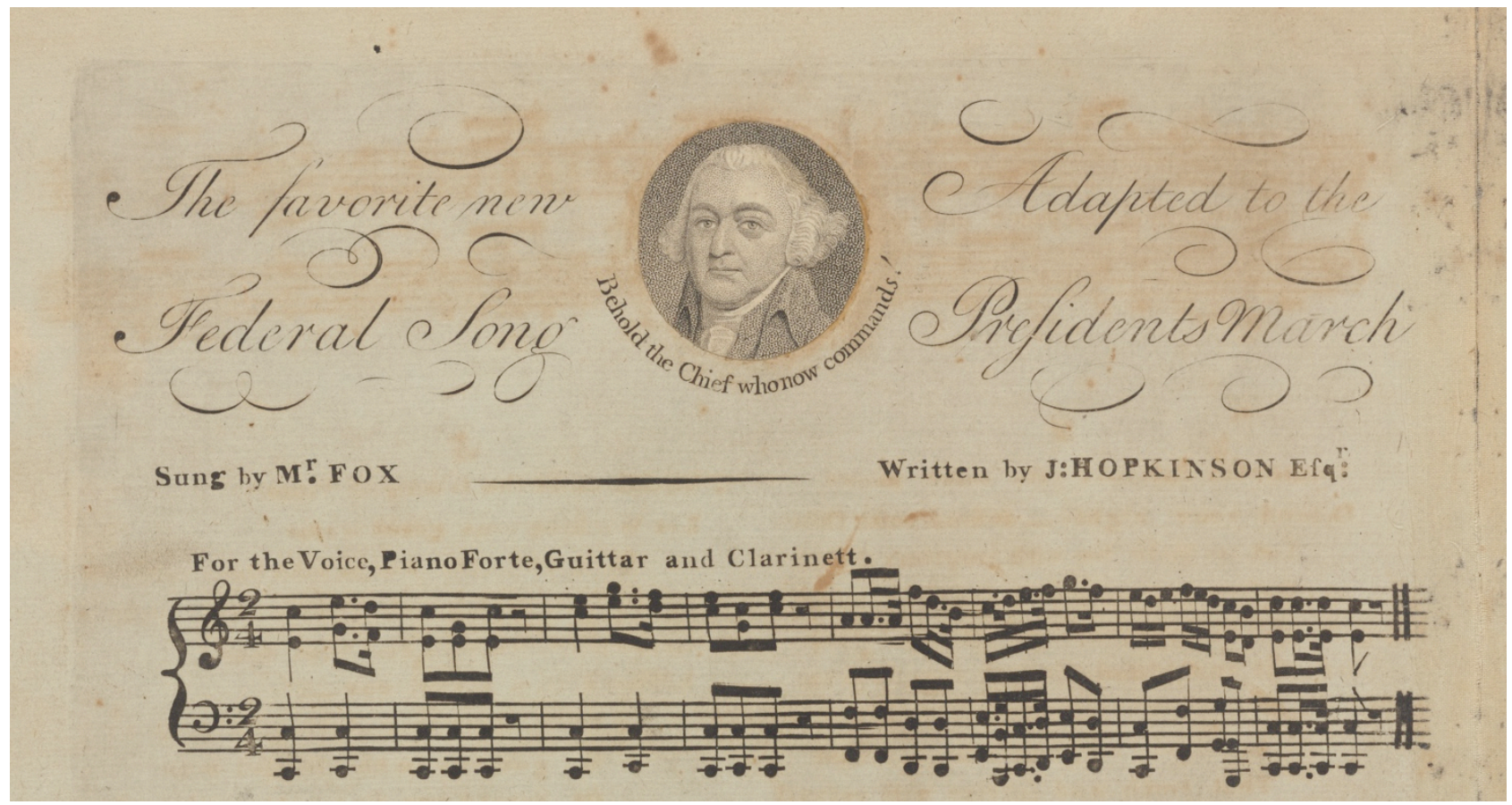

Figure 1b: Adams Portrait 2 (New York Public Library for the Performing Arts) 
Figure 1 (cont.): Variants of "Hail Columbia" ([Philadelphia: Carr, 1798]), title area and opening system.

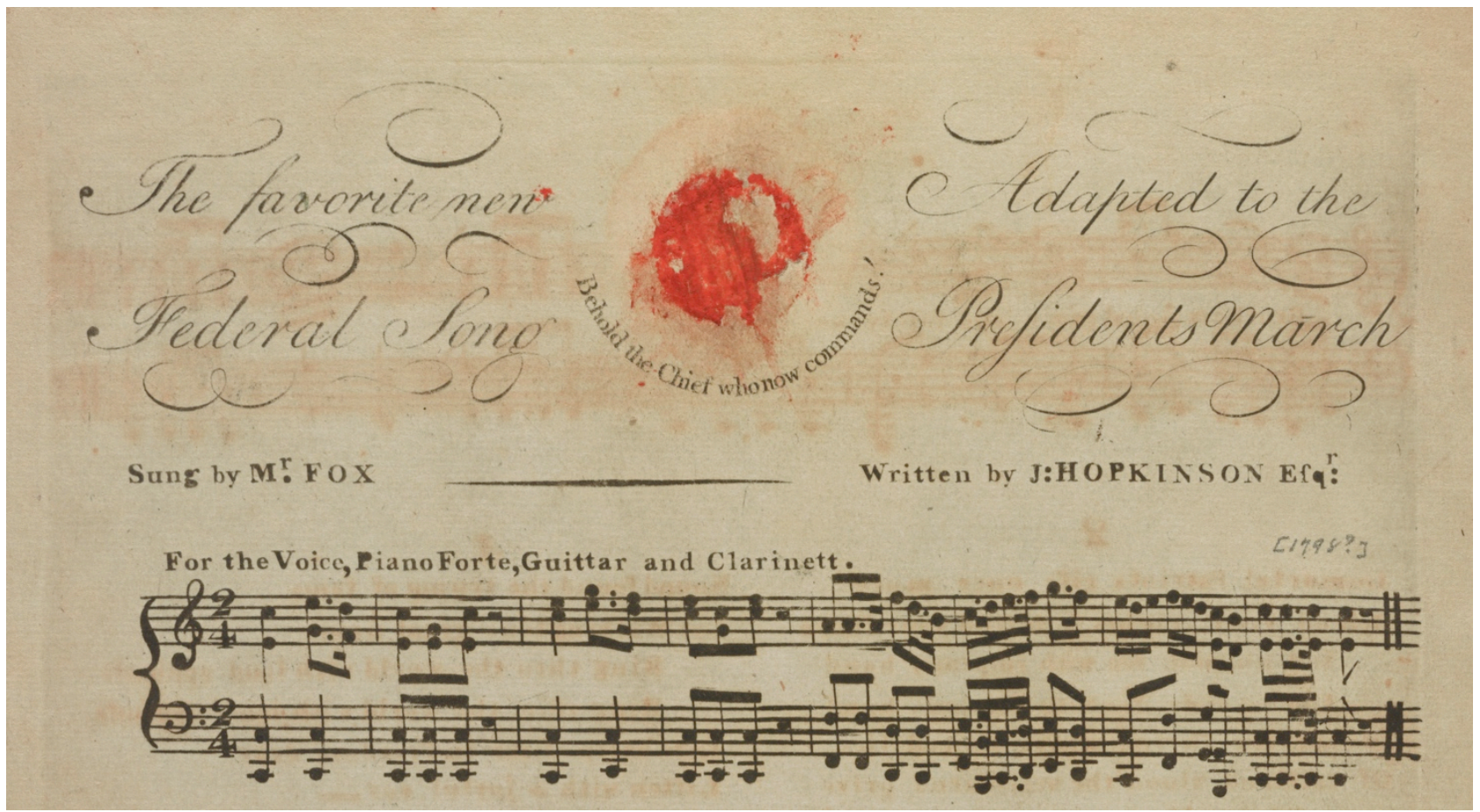

Figure 1c: Removed Portrait (Music Division, Library of Congress)

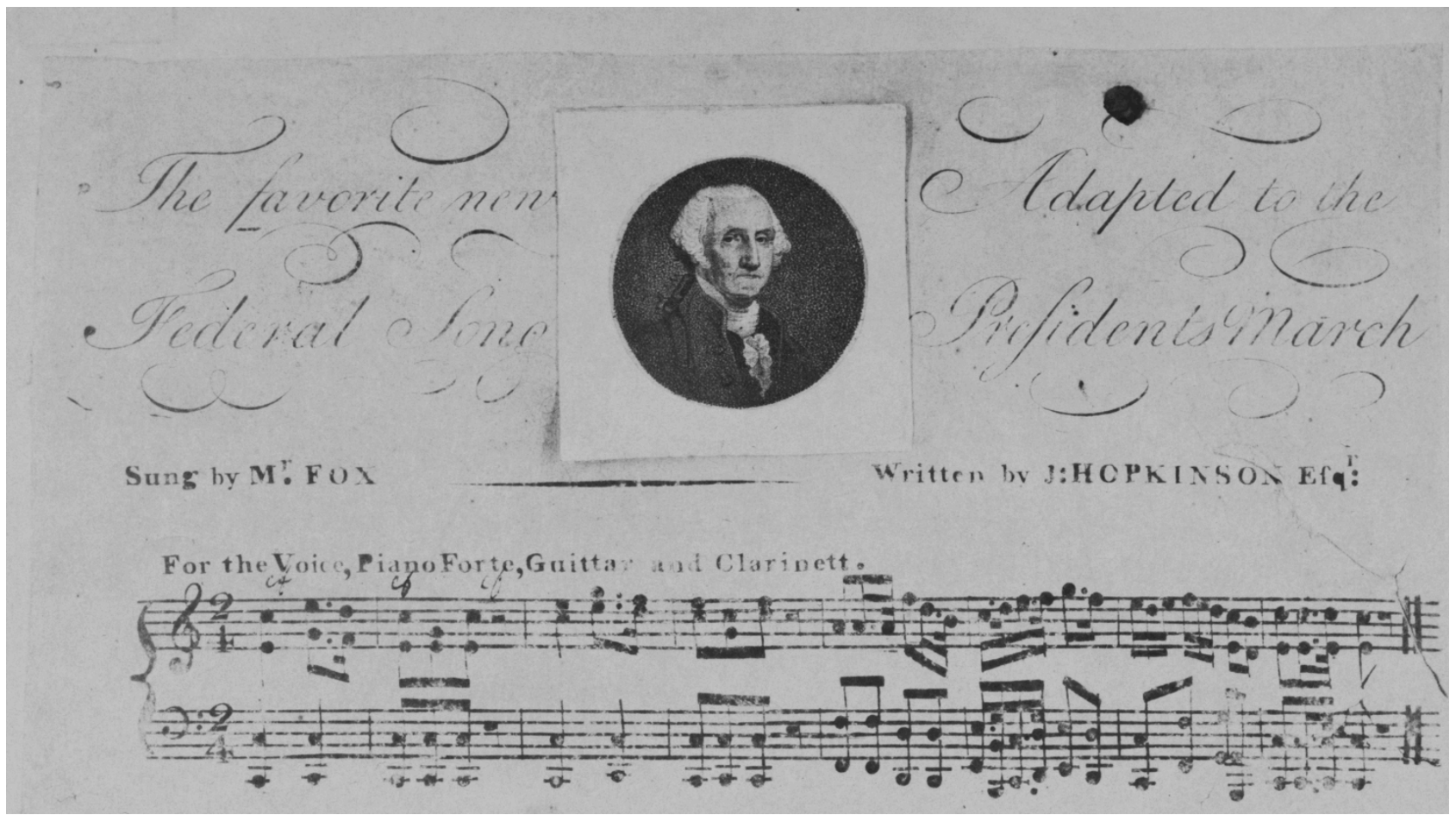

Figure 1d: Washington Portrait (Music Division, Library of Congress) 
a way of affirming his virtue and identifying as a deferential citizen. Vision, physiognomy, moral character, and nationalism therefore coalesced in a popular fascination with the presidential countenance. ${ }^{44}$

If there is one moment when Upton's assertion concerning the unbiased sentiment of "Hail Columbia" acquires some legitimacy, it is when Carr imposed a more permanent image on his edition of the song. For reasons that are obscure, he effaced the circular legend ("Behold the chief who now commands"), and in its place he engraved (or had engraved) an eagle with a shield in its beak, backed by rays of light bursting through dark clouds (Fig. 2). ${ }^{45}$ This was standard American iconography, of a more abstract and ideologically flexible variety than honorific portrayals of Washington and Adams. It is unlikely that such an image would have offended Republicans. But in light of the existing Federalist associations of "The President's March" and the words that Hopkinson set to it, this illustration appears as an attempt to clothe the ruling ideology in the trappings of disinterested citizenship. In this regard it is not unlike the dozens of written endorsements of Adams assembled by the Boston printer John Folsom in the same year. Although these petitions backed a partisan agenda, their collective publication made the Adams administration look like an organic representation of an undivided populace. The products of local meetings orchestrated by Federalists from Maine to Georgia, they created the impression of a nation instinctively united in its support of the federal government. But that unanimity was less a reflection of the state of public opinion than a species of propaganda. The compiled addresses professed to be "a summary of American, popular sentiment, on the genuineness of which you may rely," in which the mayor, aldermen, and citizens of Philadelphia, for instance, congratulated Adams "on the prospect of unanimity that now presents itself to the hopes of every American, and on the spirit of independent patriotism that is rapidly rising into active exertion." ${ }^{46}$ But Republicans were not fooled by efforts to cloak Federalism in expressions of affective nationalism. "Let the history of the federal government instruct mankind," warned the Aurora, "that the masque of patriotism may be worn to conceal the foulest designs against the liberties of a people." ${ }^{\prime 7}$ Subtler than a portrait of Washington or Adams, this illustration was less on the nose but no less partisan in intent.

From these interventions in the publication of "Hail Columbia," it is clear that Carr gave special attention to this song. To my knowledge his was the first instance of a substitutable image in the caption area of an American music sheet. The illustration of American sheet music in general would not become a widespread phenomenon for decades. Yet Carr's investment in this song is not only evident in the paratextual realm of illustration; it is discernable in the music as such. A parody song is not a scenario where one expects to find significant musical innovation. By definition it is a composition in which the music stays the same, but Carr introduced a small but important modification.

\footnotetext{
${ }^{44}$ Waldstreicher, Perpetual Fetes, 119-23. Waldstreicher argues that “the obsession with Washington's face replaced the monarchical focus on the king's body, doing so in a way particularly amenable to the requirements of a national print culture" (119).

${ }^{45}$ Two facts support the assumption that the presidential versions of the caption area came first, the eagle second. First, it would have been easier to replace the circular legend with the eagle illustration than vice versa. Second, within two days of the premiere of "Hail Columbia," Carr announced that he would publish "The very favourite NEW FEDERAL SONG, Written to the tune of the PRESIDENT's MARCH, BY J. HoPKINSON, EsQ. And sung by Mr. Fox, at the New Theatre with great applause, ornamented with a very elegant PoRTRAIT OF THE PRESIDENT" (Porcupine's Gazette, April 27, 1798, 3). It is unlikely that the eagle version intervened between this advertisement and Fox's introduction of the song to the public on April 25. ${ }^{46}$ A Selection of the Patriotic Addresses to the President of the United States (Boston: Folsom, 1798), iii-iv and 191-92. My interpretation of these addresses is indebted to Cotlar, Tom Paine's America, 107-08. Cotlar counters Ray's argument in "Public Addresses" that the petitions reflect a genuine consensus on national issues.

47 "From a Correspondent," Aurora General Advertiser, December 23, 1796, 3.
} 


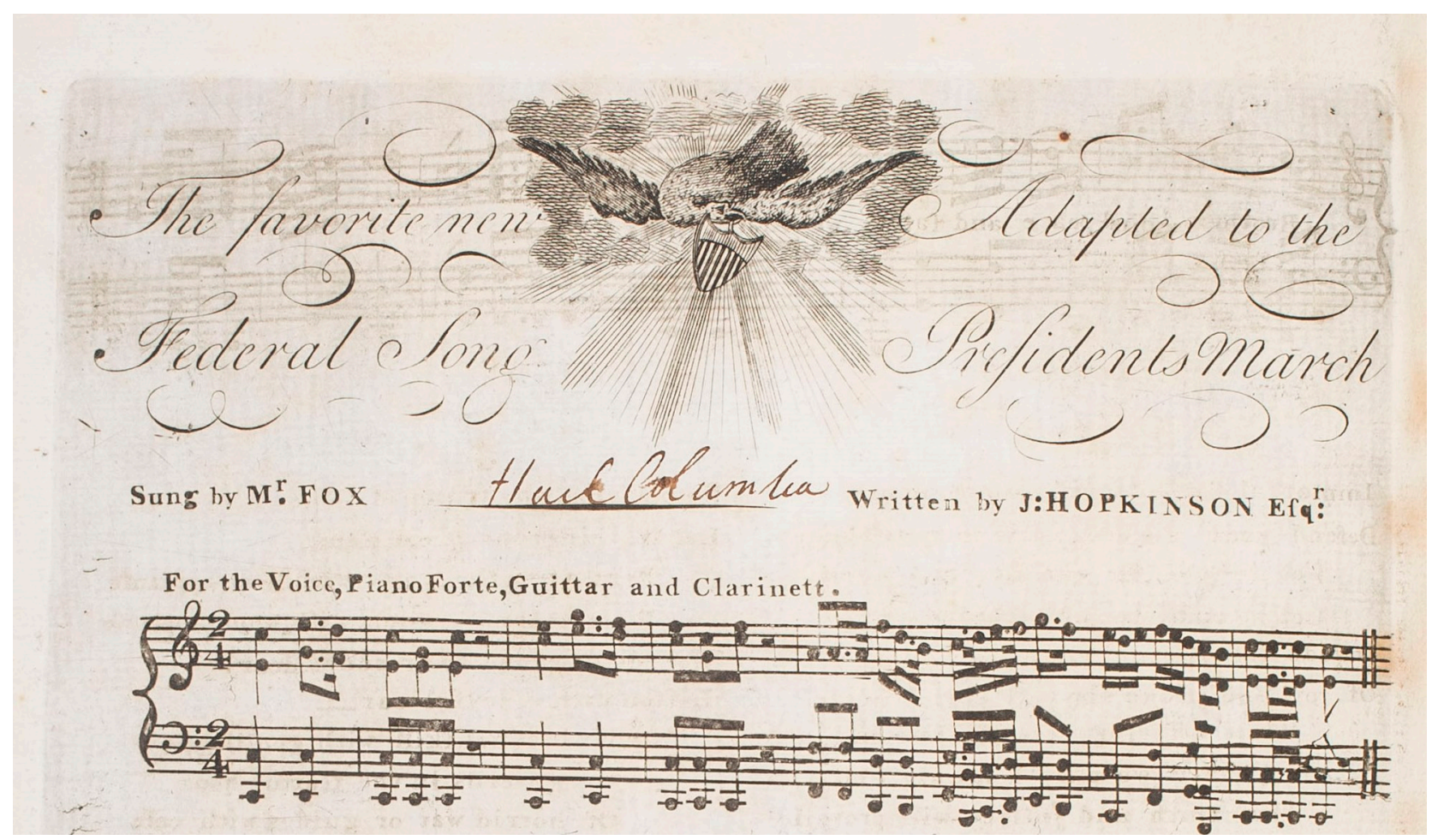

Figure 2: Variant of "Hail Columbia" ([Philadelphia: Carr, 1798]), title area and opening system. Sheet Music Collection, American Antiquarian Society.

The passage in question begins in measure twenty-one of "Hail Columbia" (Fig. 3), which corresponds to measure thirteen of "The President's March" (Fig. 4). With one exception, measures thirteen through twenty of every extant edition of "The President's March" show the same harmony as Carr's version, or a close derivative. After a cadence on the dominant in measure twelve, the B section opens with an applied dominant that resolves to the supertonic in measure fourteen. This is followed by prolonged emphasis of the dominant (mm. 15-17) and then the tonic (mm. 18-20). ${ }^{49}$ In adapting this material for use in "Hail Columbia," Carr altered the chord progression in measures fifteen and sixteen, which correspond to measures twenty-three and twenty-four in his "Hail Columbia." He evidently made this change in response to Hopkinson's text, which in those measures reads "ever mindful what it cost," referring to the sacrifices incurred in the Revolutionary War. The words strike a mournful note, and Carr accordingly extends the minor tonality into measure twenty-three. At a moment when other editions move to the dominant, Carr lingers on the supertonic, retonicizing it. He thus withholds the dominant until measure twenty-five. This deferral and minor-mode prolongation generate tension, reflecting the hardship with which independence was gained. It is a text-expressive moment in a repurposed march whose music is otherwise indifferent to its words. ${ }^{50}$

\footnotetext{
${ }^{48}$ Carr's edition of "Hail Columbia" includes a prelude and postlude that are not found in the original march. It thus comprises an additional eleven measures. In "The President's March" measure thirteen marks the onset of the B section, but in "Hail Columbia" internal repetitions are eliminated and with them the demarcation of internal sections.

${ }^{49}$ Sheets showing the same harmonization as Carr's include "President's March" (New York: Gilfert, [1797]), “The President's March” (New York: Moller, [ca. 1800]), “President's March” (New York: n.p., n.d.), and Rayner Taylor's arrangement of "The President's March" as a keyboard duet (Philadelphia: Priest, [ca. 1795]). The harmonization is also found in Gilfert's version of "Hail Columbia” (New York, [1798]). The exceptional case is Willig's "President's March" (Philadelphia: [ca. 1800]), which remains on the dominant in measures thirteen and fourteen.

${ }^{50}$ The variant also appears in Hagen's “Hail! Columbia” (Boston: [1798]), which evidently copied Carr's edition.
} 


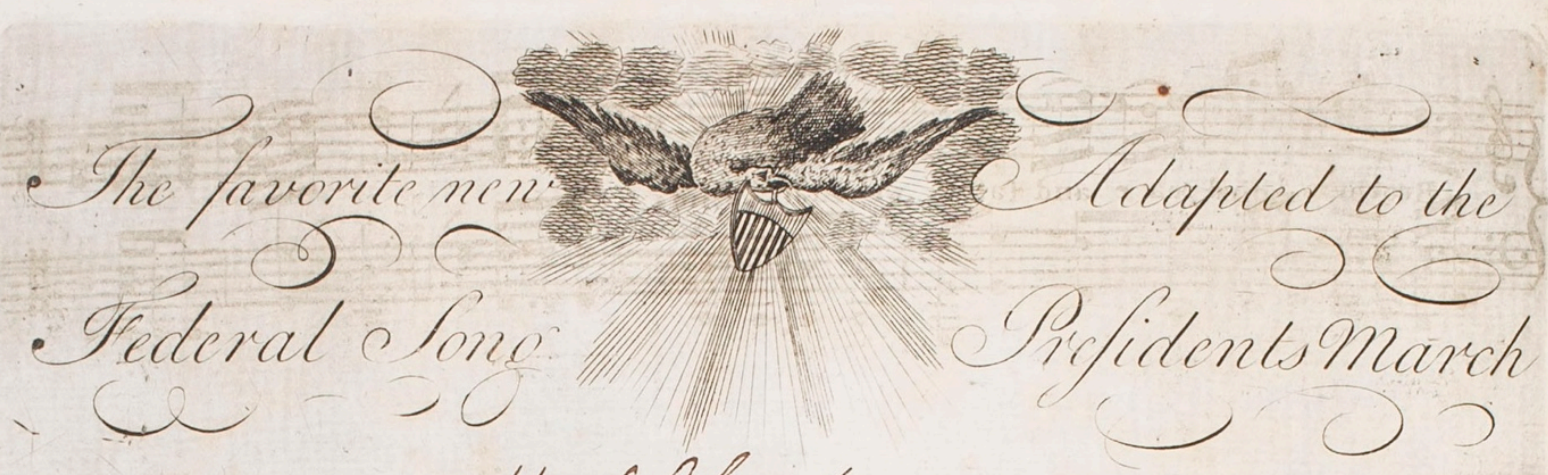

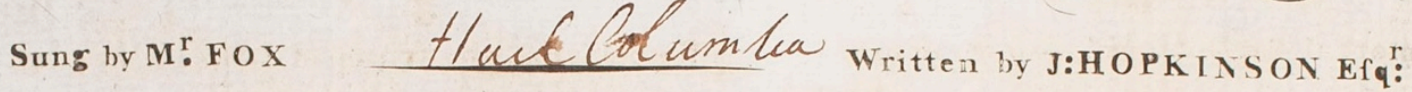

For the Voice, Piano Forte, Guittar and Clarinett.

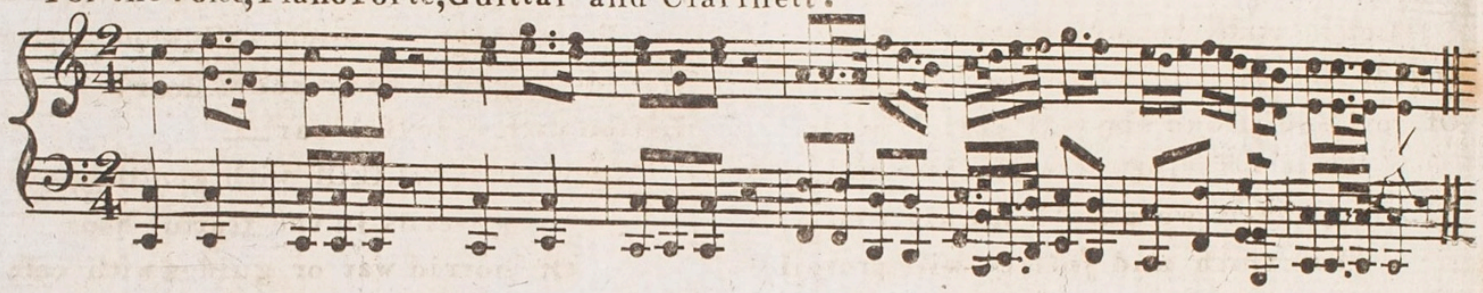

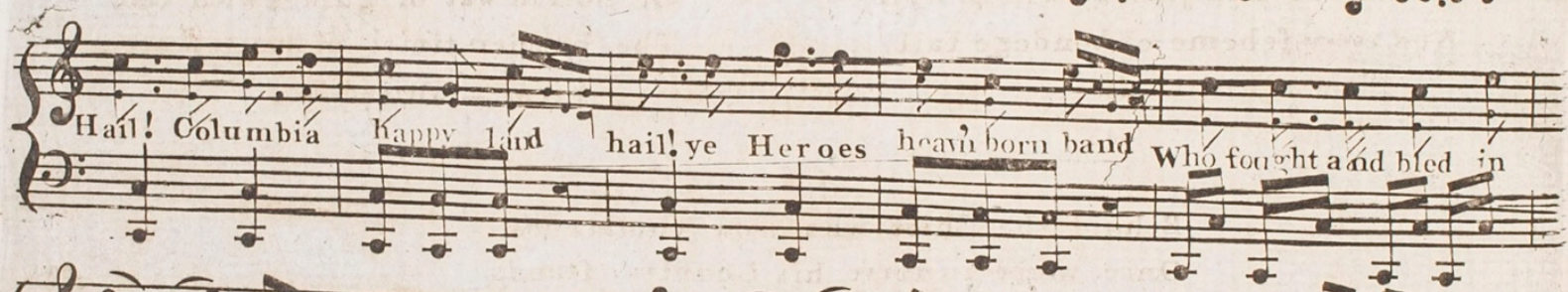

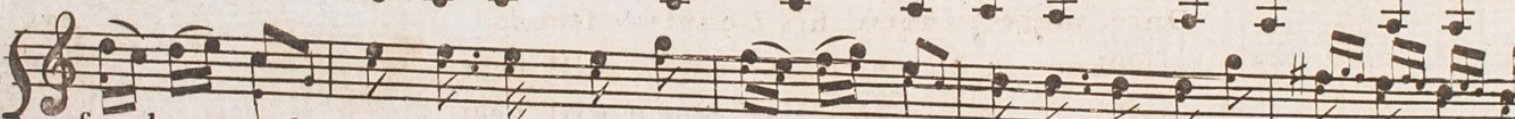

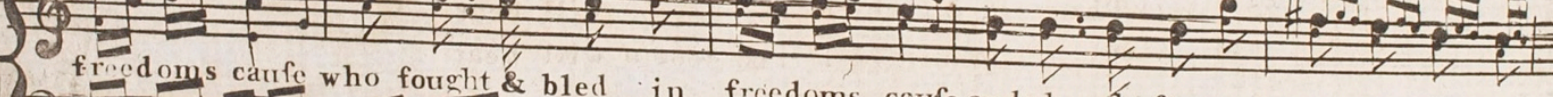

of:

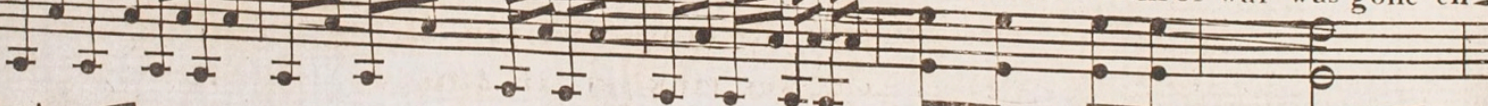

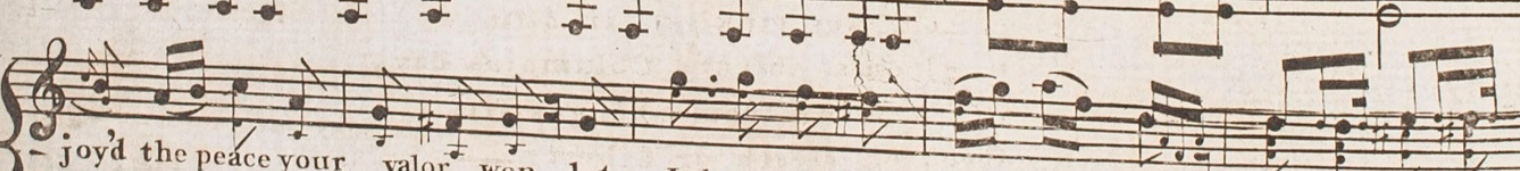

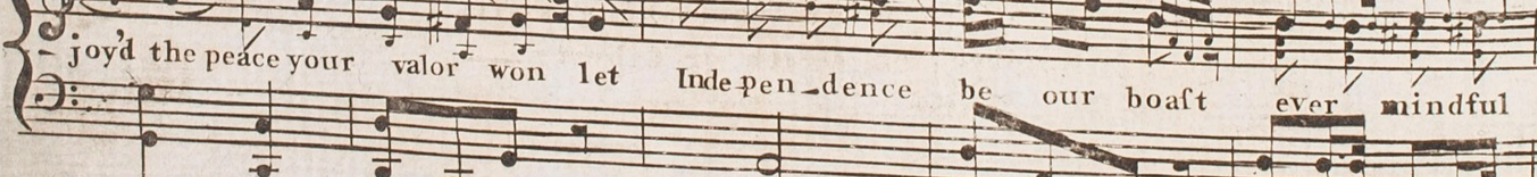

Po let Indepen_dence be our boaft ever mindful
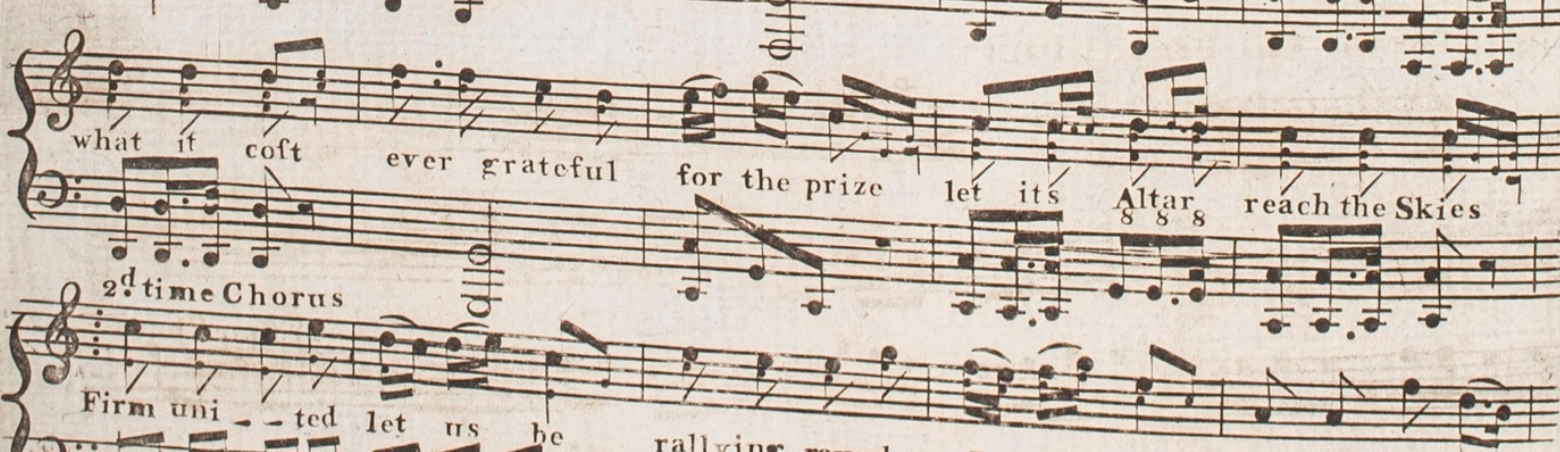

Firm uni -ted let us be rallying round our Li-ber -ty as a band of

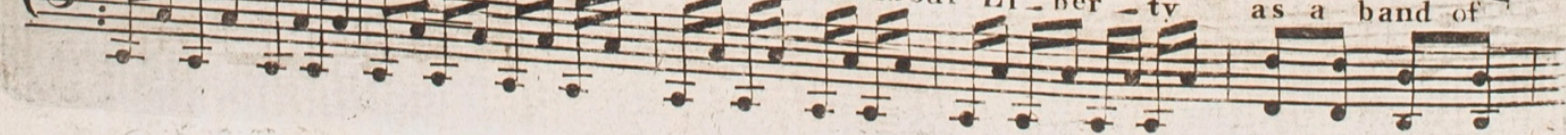

Figure 3: "Hail Columbia" ([Philadelphia: Carr, 1798]). Sheet Music Collection, American Antiquarian Society. 


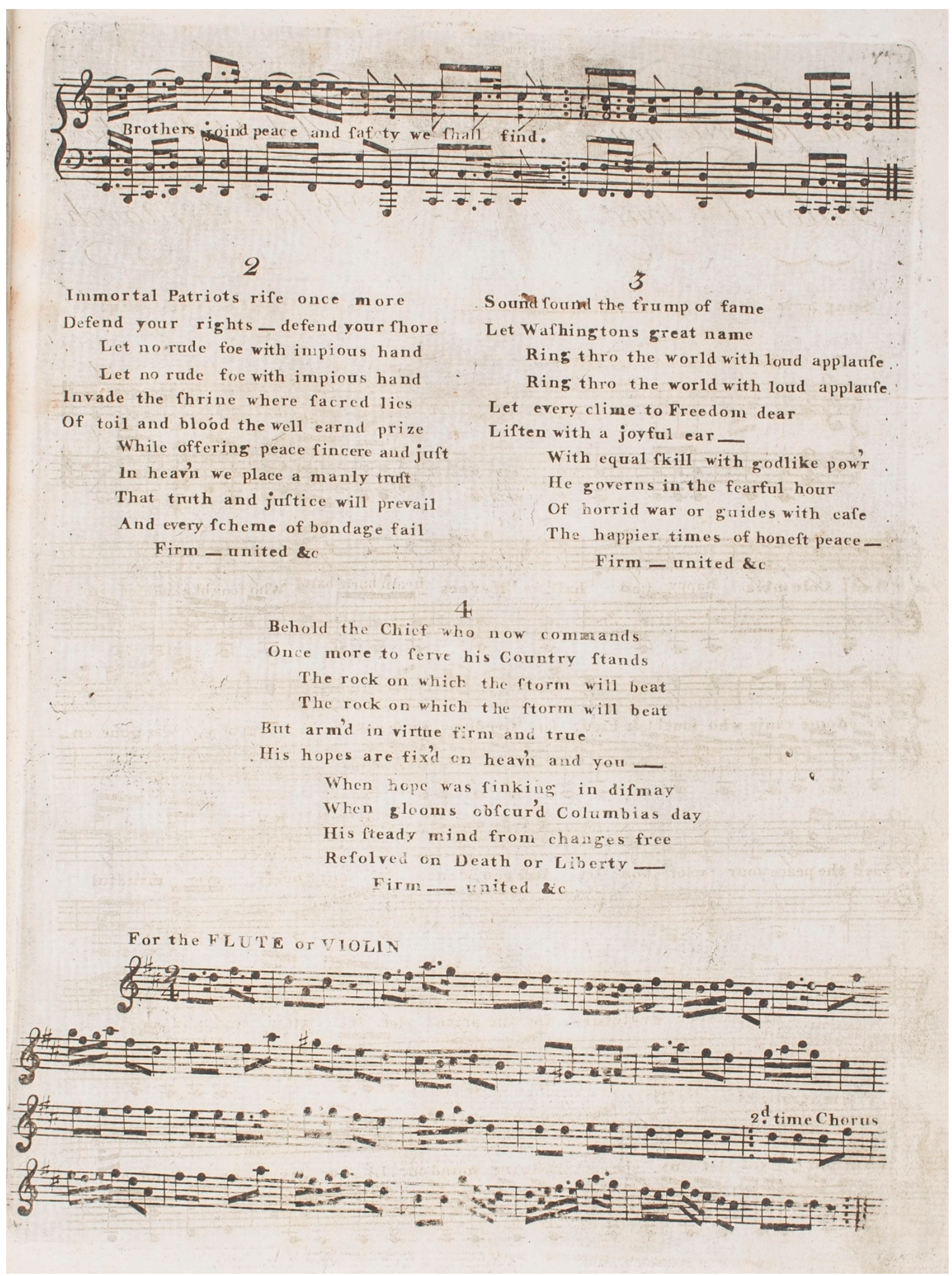

Figure 3 (cont.): "Hail Columbia” ([Philadelphia: Carr, 1798]). Sheet Music Collection, American Antiquarian Society. 


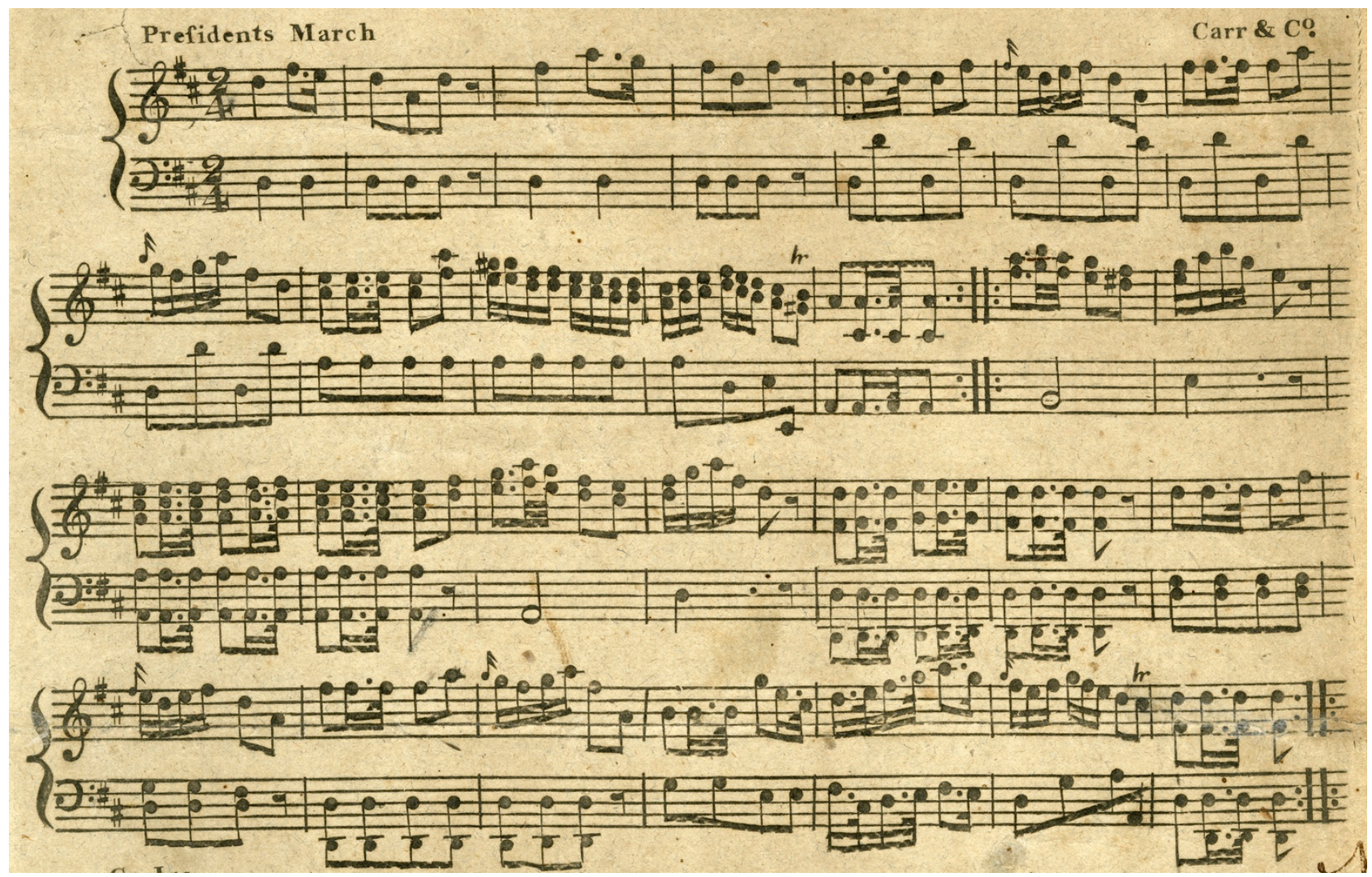

Figure 4: "President's March" (Philadelphia: Carr, [1793-94]). Keffer Collection of Sheet Music, Kislak Center for Special Collections, Rare Books and Manuscripts, University of Pennsylvania.

Though slight within the overall scope of "Hail Columbia," Carr's musical innovation cannot be discounted. That he bothered to modify the music at all is noteworthy, because his existing arrangement of "The President's March" worked perfectly well. Given the Federalist analogy between the American Revolution and the Quasi-War, Hopkinson's appeal to the cost of independence reinforced an anti-French logic. If French aggression constituted the same threat to American liberty as British imperialism, then it followed that the United States should resist French interference, period. Carr's musical intensification of Hopkinson's Revolutionary reminder was part and parcel of this line of argument.

\section{Conclusion}

Considering the high esteem in which Americans initially held republican France, the popularity of "Hail Columbia" and spin-offs like "Adams and Liberty" and "Columbia and Liberty" signals a shift in public opinion. But these songs do not merely reflect a spontaneous popular reaction to Marshall's Paris dispatches; they represent an effort to equate the French conflict with the American Revolution. Like the Alien and Sedition Acts, they exploit the Quasi-War and XYZ Affair to promote a war-ready vigilance against perceived threats to a hard-won liberty.

That this repertory is ideological in the first place and musical in the second is confirmed by its authors' reliance on preexisting tunes. Setting carefully devised topical texts to familiar melodies was a fast and unobjectionable way to flood the musical market with Federalist propaganda. The new words were the leading concern; they exhibit thematic and narrative consistency across the examples considered. The 
musical sources are less coherent, comprising melodies ranging from an American patriotic march to an apolitical social song and a British imperialist anthem. In keeping with the tradition of the parody song, the authors of these Federalist anthems wrapped contentious political messages in alluring musical packaging.

The fame of "Hail Columbia" suggests, above all, that the deterioration of Franco-American relations left a deep mark on American public consciousness. Foreign intrigue and offshore trade skirmishes became urgent domestic affairs, permeating popular culture. Early Americans viewed themselves both as members of a bounded nation-state and as constituents of an evolving geopolitical system, both as U.S. citizens and as denizens of a volatile transmaritime sphere of commercial and military action. To be American was to be connected to England and France, and "Hail Columbia" endorsed a partial perspective on those relationships. The song belongs to a heightened moment in the construction of American national identity, when Federalists opportunistically promulgated their vision of the United States' role in the history of the modern Atlantic world.

\begin{abstract}
Oscar Sonneck's century-old definition of "Hail Columbia" as a non-partisan song needs revision. The song's words and music, its promotion and reception in the Philadelphia newspapers, and the paratextual practices of representation associated with its early printed editions combine to situate "Hail Columbia" as part of an informal cultural program whereby Federalists leveraged the events of the Quasi-War and XYZ Affair to rouse support for Adams and discredit French-sympathizing Republicans. Whereas historians have heralded "Hail Columbia" as a spontaneous expression of an embryonic national spirit, and thus as transcending the partisan rancor of its day, the song ought to be studied as belonging to an effort to represent Federalist interests as the interests of the nation.
\end{abstract}

